\title{
Gestational nutrition 1: alterations to gestational nutrition can increase indicators of fertility in sheep
}

\author{
Peter Smith ${ }^{1}$, Jo-Ann L Stanton², Laurel Quirke ${ }^{1}$ and Jennifer L Juengel ${ }^{1}$ \\ ${ }^{1}$ Animal Science, AgResearch, Invermay Agricultural Centre, Mosgiel, New Zealand and '2Department of Anatomy, \\ University of Otago, Dunedin, New Zealand
}

Correspondence should be addressed to P Smith; Email: peter.smith@agresearch.co.nz

\begin{abstract}
The aim of this study was to examine the relationships between gestational nutrition, fetal ovarian development and offspring fertility in female sheep and to highlight the potential mechanisms underlying these relationships. Adult sheep $(n=79)$ were fed either a maintenance or 0.6 of maintenance plane of nutrition for the first $\mathbf{5 5}$ days of gestation and thereafter fed ad libitum. Fetuses were collected for analysis at days 55 and 75 of gestation. Female offspring were monitored from birth until 19 months of age. Effects of restricted nutrition were observed on maternal plasma concentrations of progesterone, creatinine, albumin and $\mathrm{Ca}^{2+}$ at day 55 and creatinine at day 75 . Concentrations of metabolic factors and steroid hormones in day 75 fetal plasma were not affected by the restricted maternal plane of nutrition. At day 55 of gestation, fetal ovarian germ cell development was not affected by maternal plane of nutrition. At day 75 of gestation ovaries from fetuses whose dams were exposed to restricted nutrition contained more germ cells but had lower germ cell proliferation rates than controls. For female offspring at 8 months of age, the dams gestational plane of nutrition did not affect the onset of puberty, ovulation rate (OR) and antral follicle counts (AFC). At 19 months of age, ewes from dams exposed to the restricted plane of gestational nutrition had higher OR, AFC and progesterone concentrations while concentrations of FSH were lower. In conclusion, while effects on fertility per se are yet to be determined, a reduced maternal plane of gestational nutrition can improve indicators of fertility in female offspring.

Reproduction (2019) 157 199-213
\end{abstract}

\section{Introduction}

The negative impacts of gestational undernutrition on postnatal fertility have been demonstrated in a number of species including sheep (Rae et al. 2002, Long et al. 2010), cattle (Evans et al. 2012), humans (Lumey \& Stein 1997) and rodents (Meikle \& Westberg 2001). Results vary markedly between studies, largely dependent on the type of restriction (e.g. metabolizable energy, calories and protein), the timing of nutritional restriction and the age at which offspring were studied. When compared with appropriate control groups, animals from dams exposed to restricted gestational nutrition have been reported as having lower birth rates (Meikle \& Westberg 2001, Long et al. 2010), lower ovulation rates (OR) (Rae et al. 2002), lower antral follicle counts (AFC) (Evans et al. 2012), greater FSH response to a GnRH challenge (Kotsampasi et al. 2009) and lower progesterone concentrations (Long et al. 2010).

While the mechanism(s) underlying these effects are yet to be clearly established, a number of studies have shown a relationship between fertility, AFC and ovarian reserve (Evans et al. 2012). Given that in most mammalian species the ovarian reserve is established during fetal development, mechanisms relating to germ cell development and follicle formation in the developing fetal ovary seem likely candidates to underpin the relationship between a restricted plane of gestational nutrition and postnatal fertility. A number of studies have identified differences in germ cell development in sheep ovaries from fetuses whose dams were exposed to a restricted plane of gestational nutrition including changes to germ cell proliferation and expression of apoptotic genes (Borwick et al. 1997, Rae et al. 2001, Murdoch et al. 2003, Lea et al. 2006). Of these studies, arguably the most insightful is the study of Murdoch et al. (Murdoch et al. 2003). Murdoch reported that at day 78 of gestation, germ cells in sheep fetal ovaries from dams underfed (50\% of NRC requirements) from day 28 of gestation contained elevated 8-oxyguanine content, an indicator of oxidative DNA modifications, potentially threatening the genetic character and reproductive capacity of the progeny. Further, Murdoch reported upregulation of the cell cycle arrest gene p53 (TP53), the apoptosis inhibitor $B C L-2$, and the DNA repair gene polymerase $\mathrm{B}(P O L B)$, suggesting an ovarian response to counter nutritionally induced DNA modifications.

From this background of at times conflicting results, the hypothesis underlying this study is that the adopted maternal nutritional regimen will affect both fetal ovarian 
development and female offspring fertility. Given that the mechanism underlying this relationship is yet to be established, a major focus of this study was to examine potential mechanisms underlying the relationship between gestational undernutrition and postnatal fertility in sheep. To investigate these potential mechanisms, this study used a single cohort of animals to examine the maternal metabolic and endocrine environment, fetal development (particularly germ cell development), as well as indicators of fertility, estrous cycle characteristics and endocrinology in female offspring.

\section{Materials and methods}

\section{Animal model}

All animal manipulations were carried out in accordance with the 1999 Animal Protection (Codes of Ethical Conduct) Regulations of New Zealand and were approved by the Invermay Agricultural Centre Animal Ethics Committee.

Five-year-old Romney $\times$ Coopworth ewes $(n=100)$ with a history of either single or twin lambing and a narrow weight range (65-72 kg) were selected for this study and initially grazed on pasture allocations calculated to maintain body weights. Prospective maternal ewes were fitted with intra-vaginal progesterone releasing devices (Eazi-Breed CIDR Sheep and Goat Insert. Zoetis NZ Ltd, Auckland, NZ). After 10 days, the CIDR was replaced with a fresh device for a further 3 days. Following CIDR removal on day 13 , ewes were exposed to vasectomized rams. During this cycle 80 ewes with the tightest synchronization were incrementally introduced to an indoor diet over 8 days, culminating in the animals being housed indoors and fed a maintenance diet for 5-9 days. Fresh drinking water was freely available throughout the experiment. One ewe failed to adjust satisfactorily to the diet and was removed from the trial. On the second cycle following synchronization intact rams were introduced. From the day of mating, 40 ewes were placed on a diet equivalent to 0.6 of maintenance $(R)$ and 39 ewes were placed on a maintenance $(M)$ diet. Group diets were based on metabolizable energy requirements ( 14.5 megajoules of metabolizable energy) calculated using the formula $0.6 \times$ ewe weight $(\mathrm{kg})^{0.75}$. Analysis of diet components and comparisons between maintenance and restricted intakes are presented in Supplementary Table 1 (see section on supplementary data given at the end of this article). Daily $\mathrm{M}$ diets consisted of $1.7 \mathrm{~kg}$ commercial silage, (ME $9.2 \mathrm{MJ} /$ kg DM. Fiber Ezy, Fiber Fresh Feeds Ltd, Reporoa, NZ), 0.4 kg sheep lucerne pellets (ME 9.7 MJ/kg DM. Reliance Stockfoods, Dunedin, NZ) and $0.5 \mathrm{~kg}$ lucerne chaff (ME $10.5 \mathrm{MJ} / \mathrm{kgDM}$. Sergeant Dan Stockfoods, Gore, NZ). Restricted (R) diets were $0.6 \times$ maintenance quantities (i.e. $1.0 \mathrm{~kg}$ silage, $0.24 \mathrm{~kg}$ sheep pellets, $0.3 \mathrm{~kg}$ lucerne chaff). In general, ewes were fed in groups of four to seven animals. Individual bins containing a single ewe's ration were simultaneously placed in the pen and feeding was monitored. To ensure each ewe consumed only its ration, those ewes displaying either slow or rapid feeding were penned and fed singly. At day 55 of gestation, all maternal ewes were returned to pasture (ryegrass/white clover) and fed ad libitum (allocation of $2.5 \mathrm{~kg} \mathrm{DM} /$ day, maintenance diet equates to $1.1 \mathrm{kgDM} /$ day) for the remainder of gestation. Upon the return to pasture, decreasing quantities of the indoor diet were made available for 7 days to aid the transition to a pasture diet. From birth, all offspring remained in a single group on pasture with allocations ranging from $0.7 \mathrm{~kg} / \mathrm{dm} /$ day to $1.2 \mathrm{~kg} \mathrm{DM} /$ day (age dependent) and free access to water.

\section{Fetal collections and processing}

Twenty-two ewes at day 55 of gestation and 15 ewes at day 75 of gestation were killed by barbiturate overdose $(20 \mathrm{mls}$ i.v. of Pentobarb 500, Provet NZ Pty Ltd, Auckland, NZ). Fetuses ( $n=59,30$ females and 29 males) were recovered. A $10 \mathrm{~mL}$ blood sample was collected from day 75 fetuses by cardiac puncture. Body weights, crown rump lengths and organ weights were recorded. The left ovary was fixed in $4 \%$ paraformaldehyde overnight at $4^{\circ} \mathrm{C}$. Following an overnight rinse in $70 \%$ ethanol, ovaries were dehydrated, cleared and embedded in paraffin. Ovaries were serial sectioned at $5 \mu \mathrm{m}$ with sections mounted on superfrost plus slides. Every 10th and 11th section was stained with hematoxylin and eosin. The remaining sections were stored at $4^{\circ} \mathrm{C}$ until required for immunohistochemistry.

\section{Assessment of fertility indicators in female offspring}

Thirty-seven ewes progressed to lamb, producing 13 female lambs from 12 restricted dams, and 17 female lambs from 13 maintenance dams (four additional maintenance lambs did not survive to puberty and have been excluded from analysis other than for litter size). Lambs were monitored from birth until 19 months of age. Onset of puberty (between 6 and 9 months of age) and estrus activity (18-19 months of age) was monitored using vasectomized rams fitted with marking crayons. At 19 months of age, estrous cycles were synchronized as described earlier with the inclusion of a $0.7 \mathrm{~mL}$ subcutaneous injection of prostaglandin at CIDR change (Estrumate, MSD Animal Health, Upper Hutt, NZ). Throughout the period from birth until 19 months of age, body weights and body condition scores (BCS) (Kenyon et al. 2014) were recorded at frequent intervals.

Over four successive reproductive cycles following the onset of puberty (8 months of age), laparoscopy was performed twice to assess OR (during cycles 1 and 3 ) and trans-rectal ultrasound scanning was performed twice to assess AFC (follicles $>2 \mathrm{~mm}$ ) and OR (during cycles 2 and 4). The same strategy was applied the following year when animals were at 19 months of age. Both laparoscopy (OR) and ultrasound scanning (OR and AFC) are proven techniques for the measurement of fertility indicators in sheep (Berlinguer et al. 2012, Edwards et al. 2015). Pubertal animals were not synchronized prior to ultrasound scanning or laparoscopy, while at 19 months of age these procedures were performed on days 4-6 of synchronized cycles. Laparoscopy was based on the method of Kelly (Kelly \& Allison 1976), and trans-rectal ultrasound scanning was performed with an Aloka SSD 900 scanner with a $7.5 \mathrm{MHz}$ trans-rectal probe (HitachiAloka Medical Ltd, Tokyo, Japan).

Plasma samples (for maternal ewes during gestation and offspring after birth) were collected by jugular vein puncture, 
all samples were collected into vacutainer tubes containing lithium heparin anti-coagulant and centrifuged at $1300 \mathrm{~g}$ for 15 min. To determine the pattern of LH secretion, 20 female offspring were fitted with indwelling jugular catheters and $10 \mathrm{~mL}$ blood samples collected every 15 min over an 8-h period on day $5-6$ of the 2 nd estrous cycle following synchronization.

\section{Hormone assays}

Both FSH and LH assays were based on those described by McNatty (McNatty et al. 1981). National Institute of Diabetes and Digestive and Kidney Diseases (NIDDK) reagents were purchased from the Los Angeles Biomedical Research Institute (Torrance, CA, USA).

\section{FSH}

Standards were prepared from NIDDK-oFSH-RP-2. lodinated tracer was prepared from NIDDK FSH-19 SIAFP. The antiserum was NIDDK-anti-oFSH-1 used at a dilution of 1:24,000. Briefly, $100 \mu \mathrm{L}$ each of sample, assay buffer (0.01 M PBS $+0.1 \%$ BSA), tracer and primary antibody were combined and incubated overnight at room temperature (RT). A sheep anti-rabbit secondary antibody $(100 \mu \mathrm{L})$ was added and incubated for $1 \mathrm{~h}$ at RT. Following the addition of $1.0 \mathrm{~mL}$ of $5 \%$ PEG in assay buffer, tubes were centrifuged at $2600 \mathrm{~g}$ for $35 \mathrm{~min}$ at $4^{\circ} \mathrm{C}$. Decanted tubes were then counted (Wallac Wizard, Perkin Elmer). Detection limit was $0.1 \mathrm{ng} / \mathrm{mL}$. Inter-assay CV was $11 \%$ and intra-assay $\mathrm{CV}$ was $9 \%$.

\section{$L H$}

Standards were prepared from a highly purified ovine $\mathrm{LH}$ preparation (CY1085). lodinated tracer was prepared from NIDDK-oLH-I-4. The antiserum was NIDDK rabbit-antioLH-1 used at a dilution of 1:60,000. Briefly $100 \mu \mathrm{L}$ sample, $200 \mu \mathrm{L}$ assay buffer (0.01M PBS, $0.37 \% \mathrm{w} / \mathrm{v}$ EDTA, $0.1 \%$ BSA) and $100 \mu \mathrm{L}$ primary antibody were combined and incubated overnight at $4^{\circ} \mathrm{C}$. Standards contained $100 \mu \mathrm{L}$ standard, $100 \mu \mathrm{L}$ buffer, $100 \mu \mathrm{L}$ primary antibody and $100 \mu \mathrm{L}$ of hypophysectomized sheep serum). Tracer was added (100 $\mu \mathrm{L})$ and tubes were incubated overnight at $4{ }^{\circ} \mathrm{C}$. A sheep anti-rabbit second antibody was added $(100 \mu \mathrm{L})$ followed by an overnight incubation at $4^{\circ} \mathrm{C}$. After the addition of $0.1 \mathrm{M}$ PBS containing $0.2 \% \mathrm{v} / \mathrm{v}$ normal rabbit serum, tubes were centrifuged at $2600 \mathrm{~g}$ for $35 \mathrm{~min}$ at $4^{\circ} \mathrm{C}$. Decanted tubes were then counted. Detection limit was $0.2 \mathrm{ng} / \mathrm{mL}$, inter-assay CV was $12 \%$ and intra-assay $\mathrm{CV}$ was $8 \%$.

\section{Progesterone}

Maternal progesterone was measured using the Siemens Coat-a-Count kit (Siemens Healthcare Diagnostics) following the manufacturer's instructions as previously published (O'Connell et al. 2013). Progesterone in adult offspring was measured using the IBL Coat-a-Count RIA (IBL, Hamburg, Germany, Cat MG12171). This assay required an overnight incubation at $4^{\circ} \mathrm{C}$. All other steps followed the manufacturer's instructions. Serially diluted samples produced measured values with $<5 \%$ deviation from expected values. Samples spiked with standards produced recovery rates averaging $102 \%$. Detection limit was $0.2 \mathrm{ng} / \mathrm{mL}$, inter-assay CV was $7.5 \%$ and intra-assay CV was $9.5 \%$.

\section{LC-MS measurement of maternal and fetal steroids}

Liquid chromatography mass spectroscopy (LC-MS) was used to measure steroid concentrations in maternal plasma at days 55 and 75 and day 75 fetal plasma. Measurements were performed in the laboratory of Professor David Handlesman at the ANZAC Research Institute, Sydney, Australia. The method has been published previously (Harwood \& Handelsman 2009).

\section{Metabolic factors}

Metabolic factors were measured in maternal plasma at days 55 and 75 and in fetal plasma at day 75. Measurements were performed by Gribbles Veterinary Labs (Mosgiel, NZ). All assays were photometric assays performed using a RocheHitachi Clinical Analyzer. The laboratory is IANZ accredited to NZS ISO/IEC 17025:2005. All assays were performed using standard protocols which meet the accreditation criteria.

\section{Fetal ovarian development}

\section{Immunohistochemistry}

Immunostaining for proliferating cells and cells undergoing autophagy used the Dako Envision system following the manufacturer's instructions (Dako Envision + Dual Link systemHRP DAB+. Cat K4065, Dako A/S, Produktionsvej 42, DK-2600, Denmark). For proliferating cells, a monoclonal mouse antihuman Ki-67 (type IgG1), clone MIB1 was used (Dako, Cat M7240. RRID AB_2142367) at a dilution of 1:50. Antigen retrieval was performed at $95^{\circ} \mathrm{C}$ in $10 \mathrm{mM}$ EDTA pH 8 for $20 \mathrm{~min}(2 \times 10 \mathrm{~min}$ incubations). For autophagy, a monoclonal mouse anti-MAPLC3B antibody was used (type IgG2b, Santa Cruz Biotechnology, Cat sc271625. RRID AB_10714949) at a dilution of 1:100. Antigen retrieval was performed at $95^{\circ} \mathrm{C}$ in $10 \mathrm{mM}$ citrate buffer $\mathrm{pH}$ 6.0, for $10 \mathrm{~min}$. For negative controls, the antibody was substituted for the appropriate IgG control (for Ki-67 mouse IgG1, Dako X0931: for MAPLC3B mouse IgG2b, Dako X0944). Apoptotic cells were detected using the Trevigen TACS 2 TdT-DAB In situ Apoptosis Detection kit (Trevigen, Gaithersburg, MD, USA. Cat 4810-30-K) following the manufacturer's instructions. Negative controls were based on removal of the TdT enzyme, and positive controls included nuclease enzyme in the TdT incubation step.

For both proliferation and apoptosis, positive staining cells were counted in the cortex of whole sections (3-4 sections per ovary). This number was divided by the area of the cortex to produce a relative density value of positive cells per unit area of cortex. For autophagy, three micrographs were taken from randomly selected fields of ovarian cortex from two to three sections of each fetal ovary (total of 6-9 micrographs per ovary). Micrographs were taken at the same magnification $(400 \times)$ under identical illumination conditions. Relative staining was quantified 
using image analysis software (Nikon NIS Elements Basic Research Ver 3.07). Briefly, a threshold was set to select the regions of positive staining within a standard counting frame. The area, the average density and brightness of the positive staining was calculated.

\section{Ovarian volumes and germ cell numbers}

Fetal ovarian and cortical volumes at day 55 and 75 of gestation were estimated using the Cavalieri principle (Gundersen \& Jensen 1987). Germ cell numbers were estimated using the physical dissector (Sterio 1984). Both methods have been applied to fetal ovaries previously and are described by Smith and colleagues (Smith et al. 1993). In this instance, volumes were calculated from every 20th section and the physical dissector was applied to every 50th and 51 st section.

\section{Statistical analysis}

Statistical procedures were performed using the Genstat statistical software package (17th edition, VSN International, Hemel Hempstead, UK). For all data, the experimental unit ( $n$ value) is the number of dams. In the case of fetal weights, offspring OR, AFC and progesterone, data from multiple fetuses/offspring from a single dam were averaged prior to analysis. For remaining assays (fetal and offspring), stereology and immunohistochemistry, a single female fetus or ewe from each dam was analyzed. Where a continuous time variable was present, a repeated measures analysis of covariance (RMANCOVA) was applied. Where a discrete time/age variable was present, a general linear model (GLM) was initially applied with age/time and nutritional group in the model. Where GLM indicated a significant interaction or a trend $(P<0.1)$, ANOVA was applied to analyze either groups or ages separately. The Bonferroni multiple range test is reported on two occasions, where differences followed a clear pattern related to the biology. These are, offspring progesterone where differences are identified early in the estrous cycle, and offspring FSH where differences are identified following emergence of the first follicle wave. Data relating to fetal ovarian development were normalized by log transforming prior to analysis. For all LC-MS steroid concentrations, where values were below the detection limit, expected values were generated using an iterative algorithm as described by Gleit (Gleit 1985).

For analysis of the pattern of LH secretion, for each sheep, from the 33 samples measured over the 8-h period, the average of the ten lowest values was taken to be the basal secretion value. Values over 10 S.D. above basal values were considered a major peak, while values between three and 10 S.D. above basal values were considered minor peaks. To be considered a peak, at least one value had to fit the criteria where the proceeding value did not. This strategy was based on that described by Goodman and Karsch (Goodman \& Karsch 1980). Observation of individual LH profiles revealed the presence of minor peaks in the profiles of most animals. As minor LH peaks have been described in sheep previously (Clarke \& Cummins 1987), the strategy was developed to include these minor peaks.

\section{Results}

\section{Maternal and fetal characteristics}

\section{Maternal body weights}

Maternal weights during early to mid-gestation are presented in Fig. 1. At the time feeding regimes were introduced, the average weight of the 39 animals assigned to the maintenance group was $70.3 \mathrm{~kg} \pm 0.6$ with an average BCS of $3.2 \pm 0.04$. The average weight of the 40 animals assigned to the restricted group was $70.4 \mathrm{~kg} \pm 0.6$ with an average BCS of $3.3 \pm 0.04$. At cessation of the nutrition regimes at day 55 of gestation, maintenance animals weighed $72.4 \mathrm{~kg} \pm 0.6$ (gain of $2.1 \mathrm{~kg}$ ) and their BCS remained at $3.2 \pm 0.04$. By comparison, the restricted animals on average had lost $5.0 \mathrm{~kg}$, completing the restricted nutrition regime with an average weight of $65.4 \mathrm{~kg} \pm 0.5$ and a BCS of $2.6 \pm 0.06$ (a loss of 0.7 in BCS). RMANCOVA analysis indicated effects of day of pregnancy $(P<0.01)$ and nutritional group $(P<0.01)$ on body weight, with a group $\times$ day of pregnancy interaction $(P<0.05)$. Differences between nutritional groups were evident from day 10 post mating and continued until the last recorded gestational weight at day 90. From day 55, at the completion of restricted nutrition, until the final recorded gestational weight at day 90, restricted animals showed a greater weight gain than maintenance animals. During this period, restricted animals gained an average of $5.9 \mathrm{~kg} \pm 0.6$, while

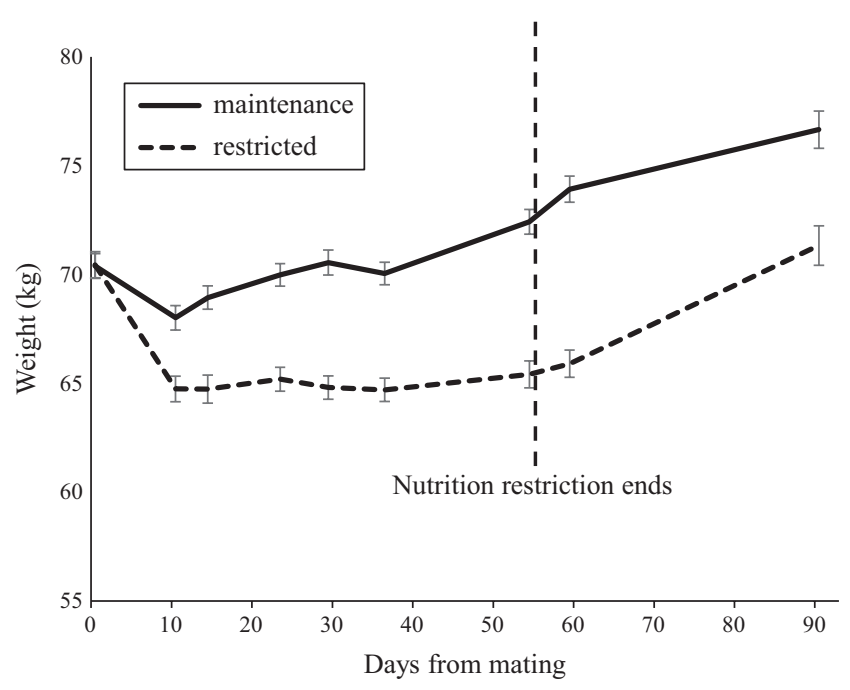

Figure 1 Effect of altered nutrition on maternal weights early - mid gestation. Results are presented as means and standard errors following nutrition restriction from day $0-55$ of gestation and ad libitum nutrition thereafter. Effects of day of pregnancy $(P<0.01)$, and nutritional group $(P<0.01)$ on body weight were noted, with a group $\times$ day interaction $(P<0.05)$, (RMANCOVA). Significant differences between groups were evident from day 10 of gestation (10 days after introduction of dietary restriction) until the last recorded weight at day 90 (35 days after introduction of ad libitum diet for all animals). 
maintenance animals gained an average of $4.3 \mathrm{~kg} \pm 0.7$ $(P<0.05)$.

\section{Fetal numbers and weights}

Restricted nutrition had no effect on the number of fetuses present in each ewe at days 55 and 75 of gestation (Table 1). There was no effect of fetal sex on fetal size or weights with the exception of gonad weight at day 75 where testes were significantly heavier than ovaries. Thus, for analysis and the data presented in Table 1, male and female data are combined with the exception of day 75 gonad weights. Restricted plane of maternal nutrition did not affect fetal crown rump length, fetal weight, kidney weight or gonad weight at either gestational age (Table 1).

\section{Concentrations of metabolic factors in maternal and fetal plasma}

In general, average maternal concentrations of metabolic factors irrespective of gestational age or group were within the normal range for New Zealand sheep (Table 2). There were effects on albumin concentrations of day of pregnancy $(P<0.01)$ and nutritional group $(P<0.01)$ and a day of pregnancy $\times$ group interaction $(P=0.02)$. The significant day of pregnancy $\times$ group interaction indicates that changes in albumin concentrations between day 55 and 75 are different between the two groups, suggesting a relatively rapid response in albumin concentrations following changes to nutrition levels. This interaction is highlighted by one-way ANOVA, where at day 55 of gestation, in response to restricted nutrition, maternal concentrations of albumin were lower in ewes on a restricted plane of nutrition compared with those on maintenance nutrition $(P<0.01)$. Whereas at day 75 of gestation, following the cessation of restricted nutrition, no significant difference in albumin concentration was apparent between the nutritional groups. There was a nutritional group effect on creatinine concentrations $(P<0.05)$ with no day of pregnancy effect or day of pregnancy $\times$ group interaction. Concentrations of creatinine were higher in restricted ewes than maintenance ewes at both days 55 and day 75 . At both gestational ages, the concentrations in restricted ewes were higher than the normal range for New Zealand sheep.

For $\mathrm{Ca}^{2+}$ concentrations, an effect of nutritional group $(P=0.05)$ and a day of pregnancy $\times$ group interaction $(P=0.04)$ were noted. The significant pregnancy $\times$ group interaction illustrates a similar situation as described for albumin concentrations. $\mathrm{Ca}^{2+}$ concentrations were lower in restricted ewes at day 55 compared with maintenance ewes $(P<0.05)$, while at day 75 , there was no nutritional group difference. $\mathrm{Ca}^{2+}$ concentrations in restricted ewes at day 55 were lower than the normal range for New Zealand sheep, while all other $\mathrm{Ca}^{2+}$ concentrations were within the normal range.

No effects of maternal plane of nutrition on metabolic factors were observed in day 75 fetal plasma (Table 2).

Table 1 Effects of altered maternal nutrition on ovine fetal characteristics at days 55 and 75 of gestation, and lamb characteristics at birth.

\begin{tabular}{|c|c|c|c|}
\hline Gestational age/variable & Maintenance & Restricted & $P$ value \\
\hline \multicolumn{4}{|l|}{ Day 55} \\
\hline Fetuses, $n$ & $7 F, 8 M$ & $8 \mathrm{~F}, 11 \mathrm{M}$ & \\
\hline Dams, $n$ & 10 & 12 & \\
\hline Litter size & $1.5 \pm 0.2$ & $1.6 \pm 0.1$ & 0.76 \\
\hline CR length $(\mathrm{cm})$ & $10.3 \pm 0.08$ & $10.3 \pm 0.1$ & 0.89 \\
\hline Weight (g) & $37.6 \pm 0.8$ & $37.6 \pm 0.9$ & 0.50 \\
\hline Gonad weight (g) & $0.013 \pm 0.001$ & $0.017 \pm 0.004$ & 0.36 \\
\hline Kidney weight (g) & $0.23 \pm 0.01$ & $0.22 \pm 0.1$ & 0.68 \\
\hline \multicolumn{4}{|l|}{ Day 75} \\
\hline Fetuses, $n$ & $7 \mathrm{~F}, 6 \mathrm{M}$ & $8 \mathrm{~F}, 4 \mathrm{M}$ & \\
\hline Dams, $n$ & 7 & 8 & \\
\hline Litter size & $1.9 \pm 0.3$ & $1.5 \pm 0.2$ & 0.09 \\
\hline CR length $(\mathrm{cm})$ & $10.2 \pm 0.1$ & $10.4 \pm 0.1$ & 0.16 \\
\hline Weight (g) & $239.1 \pm 5.8$ & $224.7 \pm 6.5$ & 0.11 \\
\hline Ovary weight (g) & $0.024 \pm 0.002$ & $0.025 \pm 0.001$ & 0.46 \\
\hline Testes weight (g) & $0.061 \pm 0.005$ & $0.048 \pm 0.007$ & 0.36 \\
\hline Kidney weight (g) & $0.212 \pm 0.018$ & $0.232 \pm 0.011$ & 0.51 \\
\hline \multicolumn{4}{|l|}{ Birth } \\
\hline Fetuses, $n$ & $17 \mathrm{~F}$ & $13 \mathrm{~F}$ & \\
\hline Dams, $n$ & 14 & 12 & \\
\hline Litter size & $1.9 \pm 0.2$ & $1.9 \pm 0.1$ & 0.89 \\
\hline Weight (kg) & $5.6 \pm 0.2$ & $5.4 \pm 0.3$ & 0.303 \\
\hline
\end{tabular}

Results are expressed as means and standard errors. Male and female data are combined for fetal characteristics with the exception of day 75 gonad weight where a significant sex effect was noted. Litter size data at birth includes four additional maintenance animals (from four dams) which did not survive until puberty. Effective $n$ value= number of dams, data from multiple fetuses from the same dam were averaged prior to analysis. 
Table 2 Effects of altered maternal nutrition on the concentration of metabolic factors in maternal and fetal plasma (day 75 female, data italicized).

\begin{tabular}{|c|c|c|c|c|c|c|c|c|c|c|}
\hline & \multirow{3}{*}{$\begin{array}{c}\text { Normal } \\
\text { range }\end{array}$} & \multicolumn{3}{|c|}{ Day 55} & \multicolumn{6}{|c|}{ Day 75} \\
\hline & & \multirow[b]{2}{*}{ Maintenance } & \multirow[b]{2}{*}{ Restricted } & \multirow[b]{2}{*}{$P$ value } & \multicolumn{2}{|c|}{ Maintenance } & \multicolumn{2}{|c|}{ Restricted } & \multicolumn{2}{|c|}{$P$ value } \\
\hline & & & & & Adult & Fetal & Adult & Fetal & Adult & Fetal \\
\hline$n$ & & 10 & 10 & & 7 & 6 & 8 & 8 & & \\
\hline Albumin* & $26-37$ & $33.3 \pm 0.54$ & $28.6 \pm 1.0$ & $<0.01$ & $27.8 \pm 0.4$ & $12.8 \pm 0.7$ & $27.3 \pm 0.9$ & $13.0 \pm 1.0$ & 0.600 & 0.721 \\
\hline Beta-hydroxybutyrate & $0-1$ & $0.44 \pm 0.04$ & $0.45 \pm 0.02$ & 0.820 & $0.4 \pm 0.05$ & $0.13 \pm 0.02$ & $0.4 \pm 0.07$ & $0.16 \pm 0.02$ & 0.665 & 0.317 \\
\hline Calcium* & $2-3$ & $2.26 \pm 0.06$ & $1.97 \pm 0.07$ & $<0.01$ & $2.2 \pm 0.1$ & $2.4 \pm 0.3$ & $2.2 \pm 0.08$ & $2.6 \pm 0.2$ & 0.734 & 0.592 \\
\hline Creatinine & 55-77 & $66.5 \pm 2.5$ & $77.9 \pm 3.7$ & 0.021 & $76.3 \pm 3.3$ & $27.4 \pm 1.6$ & $87.5 \pm 3.6$ & $26.4 \pm 1.3$ & 0.048 & 0.630 \\
\hline Magnesium & $0.85-1.29$ & $0.74 \pm 0.03$ & $0.77 \pm 0.03$ & 0.472 & $0.8 \pm 0.03$ & $0.77 \pm 0.05$ & $0.8 \pm 0.05$ & $0.77 \pm 0.04$ & 0.846 & 0.984 \\
\hline Phosphate & $1.61-2.35$ & $1.42 \pm 0.04$ & $1.27 \pm 0.07$ & 0.102 & $1.3 \pm 0.1$ & $1.9 \pm 0.1$ & $1.5 \pm 0.1$ & $1.9 \pm 0.1$ & 0.376 & 0.793 \\
\hline Triglyceride & $\mathrm{n} / \mathrm{a}$ & $0.16 \pm 0.01$ & $0.19 \pm 0.01$ & 0.107 & $0.18 \pm 0.02$ & $0.30 \pm 0.01$ & $0.23 \pm 0.04$ & $0.31 \pm 0.02$ & 0.444 & 0.814 \\
\hline
\end{tabular}

Beta-hydroxybutyrate, calcium, magnesium, phosphate and triglyceride are expressed as mmol/L, albumin in $\mathrm{g} / \mathrm{L}$ and creatinine in $\mu \mathrm{mol} / \mathrm{L}$. Results are means and standard errors. Normal ranges were provided by the testing laboratory, and are for adult non-pregnant sheep only. Each fetus analyzed was from a unique dam.

*Significant gestational age $\times$ nutritional group interaction for maternal samples $P<0.05$.

When compared with maternal concentrations at the same day of gestation, fetal concentrations of electrolytes $\left(\mathrm{Ca}^{2+}, \mathrm{Mg}^{2+}\right.$ and $\left.\mathrm{PO}_{4}{ }^{3-}\right)$ were similar. Albumin and creatinine concentrations were lower $(P<0.01)$ in fetal plasma, and the concentrations of beta-hydroxybutyrate and triglyceride were higher $(P<0.01)$ in fetal plasma when compared with maternal plasma.

\section{Circulating steroid concentrations in maternal and fetal plasma}

For progesterone concentrations measured by RIA, there was an effect of day of pregnancy $(P<0.01)$, an overall effect of nutritional group $(P<0.05)$ and no group $\times$ day of pregnancy interaction $(P=0.12)$. Ewes on restricted gestational nutrition had higher plasma concentrations of progesterone than controls at day 35 and 55 (Day 35, maintenance $5.03 \mathrm{ng} / \mathrm{mL} \pm 0.20, n=38$ and restricted $5.82 \mathrm{ng} / \mathrm{mL} \pm 0.22, n=36$; Day 55, maintenance $6.66 \mathrm{ng} /$ $\mathrm{mL} \pm 0.30, \quad n=38$ and restricted $7.78 \mathrm{ng} / \mathrm{mL} \pm 0.37$, $n=36$ ). At day 75 of gestation, there was no significant difference between nutritional groups (maintenance $9.51 \mathrm{ng} / \mathrm{mL} \pm 1.22, n=7$ and restricted $9.03 \mathrm{ng} / \mathrm{mL} \pm 1.51$, $n=8)$.

LC-MS results are presented in Table 3. For day 55 maternal samples, estradiol (E2) was detectable in 12 of 22 samples and 14 of 15 samples at day 75 . Progesterone (P4) was detectable in all maternal samples at both gestational ages. Estrone (E1), estradiol, progesterone, DHEA and $3 \beta$-androstanediol ( $3 \mathrm{~b}$ diol) were detectable in all day 75 fetal samples, but DHEA, E1 and 3b diol were not detected in any maternal samples. Testosterone, dihydrotestosterone, $3 \alpha$-androstanediol, estrone and androstenedione were not detected in either maternal or fetal samples. There were no overall nutritional group differences in any steroids measured by LC-MS in either maternal or fetal plasma (GLM). The LC-MS data for maternal progesterone follows a similar pattern to the RIA data. For maternal P4, while a GLM did not indicate a significant overall group effect, ANOVA indicated higher concentrations of P4 in maternal plasma from restricted ewes at day 55, similar to the RIA result.

\section{Fetal ovarian development}

\section{Ovarian morphology}

All fetal ovaries examined showed a typical morphological and developmental pattern as described by Smith and colleagues (Smith et al. 1993). No gross differences in the morphology of fetal ovaries attributable to maternal plane of nutrition were evident at days 55 and 75. Irrespective of nutritional group, fetal ovaries at both day 55 and 75 contained proliferating germ cells, meiotic germ cells and germ cells showing morphological signs of atresia. At day 75 fetal ovaries from both nutritional groups contained a small number of follicles.

Atresia of germ cells displayed a range of morphologies in both restricted and maintenance groups. Some germ cells displayed small dark condensed nuclei, often, although not always, accompanied by an eosinophilic cytoplasm (Fig. 2A and B black arrows). Other germ cells showed nuclei that had disintegrated. These cells in general did not show eosinophilia. A further morphology associated with germ cell atresia showed the presence of extremely large cytoplasmic vacuoles - these cells were often, but not always, associated with condensed nuclei (Fig. 2A and B red arrows). A number of germ cells were present with a pale washed out nuclei and cytoplasm (Fig. 2A and B white arrow). Some cells displaying gross atretic morphology did not stain for TUNEL (Fig. 2C black arrow), while others, also displaying atretic morphology, did not stain for MAPLC3B (Fig. 2D black arrow).

\section{Ovarian volumes and germ cell numbers}

Effects of gestational age $(P<0.01)$ and nutritional group $(P<0.05)$ were noted for ovarian volume, while no 
Table 3 Effects of altered maternal nutrition on maternal and fetal (day 75 female, data italicized) plasma steroid concentrations determined by LC-MS, and maternal P4 concentrations measured by RIA.

\begin{tabular}{|c|c|c|c|c|c|c|c|c|c|c|}
\hline \multirow[b]{3}{*}{ Hormone } & \multirow{3}{*}{$\begin{array}{c}\text { Detection } \\
\text { limit }\end{array}$} & \multicolumn{3}{|c|}{ Day 55} & \multicolumn{6}{|c|}{ Day 75} \\
\hline & & \multirow[b]{2}{*}{ Maintenance } & \multirow[b]{2}{*}{ Restricted } & \multirow[b]{2}{*}{$P$ value } & \multicolumn{2}{|c|}{ Maintenance } & \multicolumn{2}{|c|}{ Restricted } & \multicolumn{2}{|c|}{$P$ value } \\
\hline & & & & & Adult & Fetal & Adult & Fetal & Adult & Fetal \\
\hline$n$ & & 11 & 11 & & 7 & 6 & 8 & 8 & & \\
\hline DHEA (ng/mL) & 0.05 & nd & nd & & nd & $0.16 \pm 0.02$ & nd & $0.16 \pm 0.05$ & & 0.657 \\
\hline 3b diol (ng/mL) & 0.05 & nd & nd & & nd & $0.08 \pm 0.01$ & nd & $0.06 \pm 0.02$ & & 0.274 \\
\hline $\mathrm{E} 1(\mathrm{pg} / \mathrm{mL})$ & 0.125 & nd & nd & & nd & $73.07 \pm 21.32$ & nd & $59.94 \pm 6.48$ & & 0.475 \\
\hline E2 (pg/mL) & 0.25 & $0.28 \pm 0.07$ & $0.69 \pm 0.24$ & 0.190 & $1.69 \pm 0.55$ & $9.98 \pm 1.29$ & $1.04 \pm 0.22$ & $8.17 \pm 1.34$ & 0.270 & 0.398 \\
\hline $\mathrm{P} 4(\mathrm{ng} / \mathrm{mL})$ & 0.05 & $2.18 \pm 0.17$ & $2.81 \pm 0.18$ & 0.030 & $4.01 \pm 0.53$ & $0.24 \pm 0.06$ & $3.60 \pm 0.62$ & $0.21 \pm 0.02$ & 0.633 & 0.670 \\
\hline P4 $(\mathrm{RIA})^{\#}(\mathrm{ng} / \mathrm{mL})$ & 0.02 & $6.66 \pm 0.30$ & $7.78 \pm 0.37$ & 0.021 & $9.51 \pm 1.22$ & & $9.03 \pm 1.51$ & & 0.813 & \\
\hline
\end{tabular}

Results are expressed as means and standard errors.

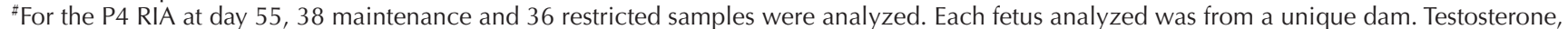
dihydrotestosterone, $3 \alpha$ androstanediol, and androstenedione were not detectable in both maternal and female fetal plasma samples. For adult E2 values, at day 55, 3 maintenance and seven restricted values were below the detection limit while at day 75, 1 maintenance value was below the detection limit. Values for these samples were generated using the methods of Gleit (1985).

$3 \mathrm{~b}$ diol, $3 \beta$ androstanediol; DHEA, dehydroepiandrosterone; E1, estrone; E2, estradiol; nd, not detectable; P4, progesterone.

gestational age $\times$ group interaction was noted, a trend was apparent $(P=0.1)$. Similarly for cortex volume, effects of gestational age $(P<0.01)$ and nutritional group $(P<0.05)$ were noted with the age $\times$ group interaction showing a trend $(P=0.09)$. There were no differences between nutritional groups at day 55 of gestation for ovarian or cortex volumes. At day 75 , fetal ovaries from dams exposed to restricted nutrition were larger $(P<0.05)$, with a larger cortex volume $(P<0.05)$ when
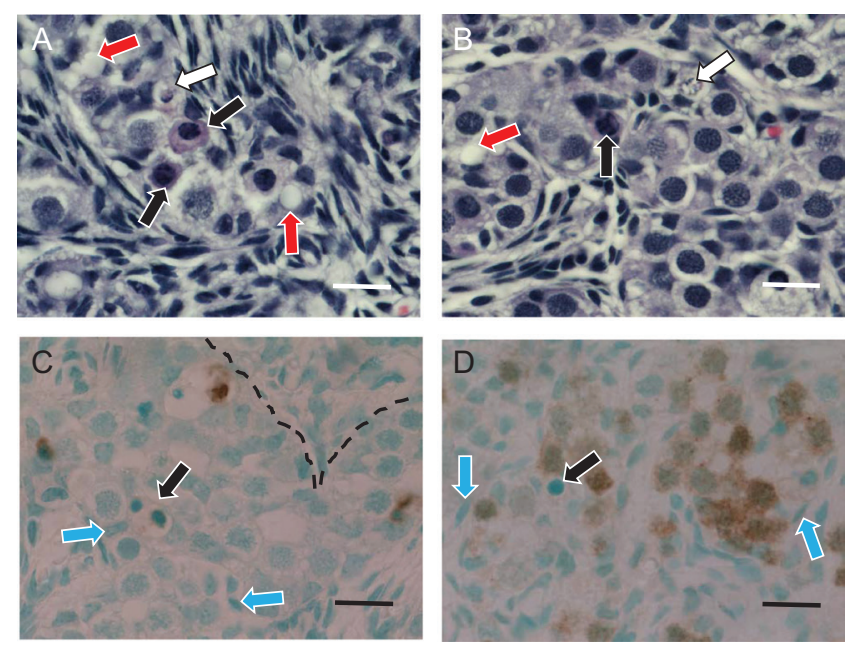

Figure 2 Differing morphologies associated with germ cell atresia. (A and B) Day 75 H\&E maintenance and restricted respectively. (C) Day 75 TUNEL maintenance. (D) MAPLC3B Day 75 restricted. Scale bars $=20 \mu \mathrm{m}$. (A and B) Black arrows illustrate germ cells with condensed nuclei and eosinophilic cytoplasm typical of apoptosis. White arrow illustrates germ cell with fragmented nuclei and pale cytoplasm. Red arrows illustrate germ cells with the presence of large cytoplasmic vacuoles. (C) Black arrow illustrates the absence of TUNEL staining in germ cell with condensed and fragmented nuclei. Blue arrows indicate pregranulosa cells. Dashed line indicates an example of the boundary between an ovigerous cord (below line) and stromal tissue (above line). (D) Black arrow illustrates the absence of MAPLC3B staining in germ cell with condensed and fragmented nuclei. Blue arrows indicate pregranulosa cells. compared with fetal ovaries from dams exposed to maintenance nutrition (see Table 4).

Germ cell numbers (Table 4) showed effects of gestational age $(P<0.01)$, and group $(P<0.01)$, with an age $\times$ group interaction $(P=0.02)$. At day 55 of gestation, there was no difference between nutritional groups in germ cell numbers, an observation also reflected in similar numbers of both oogonia and oocytes between the groups. At day 75 of gestation, fetal ovaries from dams exposed to restricted nutrition contained $46 \%$ more germ cells when compared with fetal ovaries from dams exposed to maintenance nutrition $(P<0.01)$. When examined further, the increase in germ cell number in day 75 restricted fetal ovaries was reflected in both more oogonia $(P<0.05)$ and more oocytes $(P<0.05)$. Germ cells classified as oocytes also included the relatively small number of germ cells which were enclosed in isolated follicles. The number of follicles present was insufficient for accurate quantification.

\section{Proliferating cells}

Negligible staining for Ki-67 was observed in the negative control slides (Fig. 3A). Positive staining for proliferating cells was predominantly confined to germ cells (Fig. 3B, C and D), particularly those located toward the outer most regions of the ovarian cortex (Fig. 3B and C). Positively stained germ cells often occurred in groups or clusters (Fig. 3B and C). Occasionally, cells of the ovarian surface showed positive staining (Fig. 3C). Pre-granulosa cells within the cords showed no staining. Considerable variation was noted in the number of $\mathrm{Ki}-67$ stained cells between sections. Overall, there was no effect of gestational age $(P=0.6)$, a group trend was observed $(P=0.06)$ on the density of Ki-67-positive staining cells, with no age $\times$ group interaction $(P=0.2)$. There was no difference between nutritional groups at day 55 , however at day 75 , the density of proliferating germ cells in ovaries from restricted fetuses was lower 
Table 4 Effects of altered maternal nutrition on ovine fetal ovary characteristics.

\begin{tabular}{|c|c|c|c|}
\hline Volume or cell number/age & Maintenance & Restricted & $P$ value \\
\hline \multicolumn{4}{|l|}{ Number of ovaries } \\
\hline Day 55 & 6 & 7 & \\
\hline Day 75 & 8 & 7 & \\
\hline \multicolumn{4}{|l|}{ Ovary volume $\left(\mathrm{mm}^{3}\right)$} \\
\hline Day 55 & $1.70 \pm 0.19$ & $1.93 \pm 0.19$ & 0.414 \\
\hline Day 75 & $5.23 \pm 0.37$ & $6.39 \pm 0.30$ & 0.029 \\
\hline \multicolumn{4}{|l|}{ Cortex volume $\left(\mathrm{mm}^{3}\right)$} \\
\hline Day 55 & $1.34 \pm 0.13$ & $1.53 \pm 0.14$ & 0.378 \\
\hline Day 75 & $3.81 \pm 0.26$ & $4.74 \pm 0.24$ & 0.022 \\
\hline \multicolumn{4}{|l|}{ Germ cell number* } \\
\hline Day 55 & $317,461 \pm 37,367$ & $333,484 \pm 42,472$ & 0.790 \\
\hline Day 75 & $766,344 \pm 19,070$ & $1,122,285 \pm 87,235$ & $<0.01$ \\
\hline \multicolumn{4}{|l|}{ Oogonia* } \\
\hline Day 55 & $274,217 \pm 31,414$ & $256,789 \pm 28,677$ & 0.692 \\
\hline Day 75 & $293,499 \pm 32,810$ & $453,904 \pm 32,810$ & 0.044 \\
\hline \multicolumn{4}{|l|}{ Oocytes* } \\
\hline Day 55 & $43,243 \pm 6,486$ & $76,696 \pm 21,649$ & 0.220 \\
\hline Day 75 & $472,845 \pm 41,190$ & $668,381 \pm 71,536$ & 0.041 \\
\hline \multicolumn{4}{|c|}{ Proliferating germ cells (relative density) } \\
\hline Day 55 & $0.87 \pm 0.43$ & $0.75 \pm 0 . .17$ & 0.821 \\
\hline Day 75 & $1.02 \pm 0.32$ & $0.26 \pm 0.09$ & $<0.01$ \\
\hline \multicolumn{4}{|c|}{ Apoptotic germ cells (relative density) } \\
\hline Day 55 & $2.39 \pm 0.54$ & $1.87 \pm 0.22$ & 0.835 \\
\hline Day 75 & $2.49 \pm 0.43$ & $1.96 \pm 0.15$ & 0.214 \\
\hline \multicolumn{4}{|l|}{ Autophagy area of staining } \\
\hline Day 55 & $0.0036 \pm 0.0001$ & $0.0025 \pm 0.0003$ & 0.208 \\
\hline Day 75 & $0.0013 \pm 0.0001$ & $0.0011 \pm 0.0002$ & 0.378 \\
\hline \multicolumn{4}{|l|}{ Autophagy density of staining } \\
\hline Day 55 & $0.21 \pm 0.001$ & $0.18 \pm 0.006$ & 0.097 \\
\hline Day 75 & $0.21 \pm 0.01$ & $0.19 \pm 0.01$ & 0.046 \\
\hline \multicolumn{4}{|c|}{ Autophagy brightness of staining } \\
\hline Day 55 & $62.5 \pm 3.1$ & $66.4 \pm 0.8$ & 0.119 \\
\hline Day 75 & $62.2 \pm 1.4$ & $65.2 \pm 0.4$ & 0.047 \\
\hline
\end{tabular}

Results are expressed as means and S.E.

$*$ Significant gestational age $\times$ nutritional group interaction $(P<0.05)$. Each fetus analyzed was from a unique dam.

than that observed in maintenance animals $(P<0.01$, ANOVA; Fig. 3C and D and Table 4).

\section{Apoptosis}

Negligible TUNEL staining was apparent on negative control slides (Fig. 3E inset), while intense staining over the entire section was observed on positive control slides (Fig. 3F). The pattern of TUNEL staining at both days 55 and 75 indicated that the majority of apoptotic cells were germ cells located in the ovigerous cords of the ovarian cortex (Fig. 3G and H). The few exceptions to this observation were occasional vascular endothelial cells and cells of the connecting rete in the ovarian medulla. There appeared to be no discernible pattern related to the distribution of apoptotic germ cells. Positive cells occurred throughout the ovarian cortex both individually and occasionally in clusters. The relative densities of apoptotic germ cells are presented in Table 4. There was no effect of gestational age or nutritional group on the density of apoptotic cells and no age $\times$ group interaction.

\section{Autophagy}

For MAPLC3B, staining with the negative control antibody was negligible (Fig. 3I). At day 55, staining for MAPLC3B was predominantly confined to the ovigerous cords throughout the ovarian cortex (Fig. 3J). Within the ovigerous cords, staining appeared to be exclusively within the germ cells, with pregranulosa cells showing no staining (Fig. 3M). At day 75 , staining was concentrated in the outer regions of the ovarian cortex (Fig. 3L). In general, germ cells that had completed meiosis 1 displayed less intense staining than premeiotic germ cells or those actively undergoing meiosis. Those germ cells within forming or isolated follicles displayed little or no staining. Relative staining intensities are presented in Table 4. A significant effect of gestational age on the area of MAPLC3B staining was noted $(P<0.05)$ with less staining apparent at day 75 when compared with day 55. No overall effect of group was noted, and no age $\times$ group interaction was noted on the area staining for MAPLC3B. A small group difference $(P<0.05)$ was 

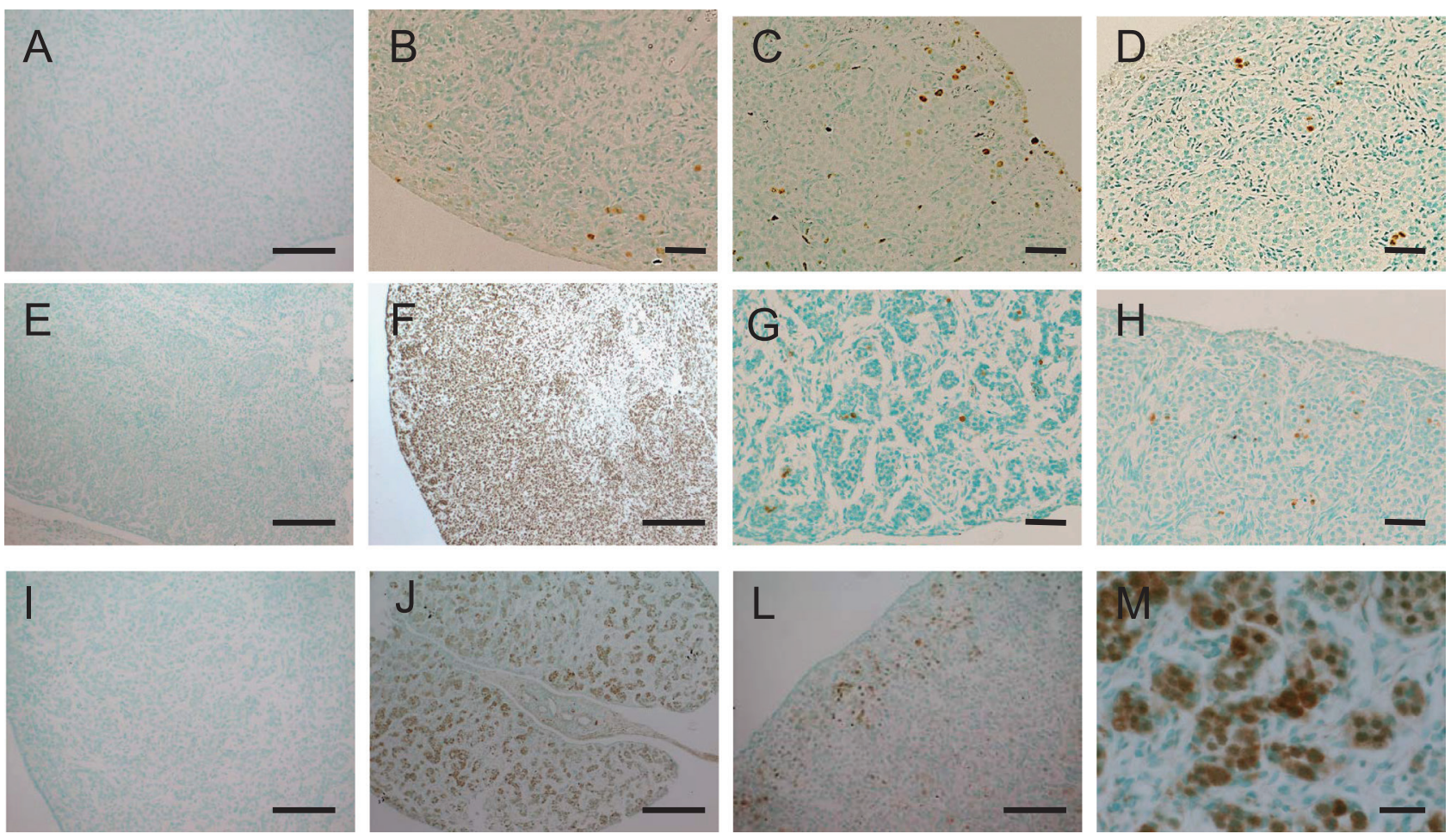

Figure 3 Immunohistochemical staining of fetal ovaries. (A, B, C and D) Ki-67, (E, F and G) Tunel and (I, J, K, L and M) MAPLC3B. Scale bars $=100 \mu \mathrm{m}$ for (A, B, C, D, E, F, G, H, I, J, K and L) and $50 \mu \mathrm{m}$ for (M). (A) Negative control. (B) Day $55=$ maintenance ovary relative density positive cells $=0.84$. (C) Day 75 maintenance ovary, relative density $=1.12$. (D) Day 75 restricted ovary, relative density positive cells $=0.35$. No difference in the density of positive staining cells was observed between day 55 and day 75 maintenance animals. At day 75 , the density of positive staining cells maintenance animals is significantly higher when compared with restricted ovaries $(P<0.01)$. (E) Negative control slide. (F) Positive control slide. (G) Day 55 restricted ovary relative density of positive cells $=1.72$. (H) Day 75 maintenance ovary relative density of positive cells $=2.08$. No group or age differences were observed in the density of positive staining cells. (I) Negative control slide. (J) Day 55 maintenance ovary, relative area of positive staining $=0.0043$. (L) Day 75 restricted ovary, relative area of positive staining $=0.0010$. (M) Day 55 maintenance ovary illustrating positive MAPLC3B staining in germ cells within ovigerous cords. No group differences were observed in the cortical area of positive staining. The cortical area of positive staining is less at day 75 compared with day 55, with staining being increasingly confined to the outer regions of the cortex. The intensity of staining was significantly higher in maintenance ovaries compared with restricted ovaries at day $75(P<0.05$, comparative images not shown).

noted in the density/brightness of the staining at day 75 with the germ cells in restricted ovaries having brighter, less dense staining (effectively indicating lower levels of MAPLC3B in these cells) compared with germ cells from maintenance ovaries.

\section{Postnatal body weights}

Of the 34 female lambs born, four did not survive to puberty. The data presented represents only those 30 female lambs which survived the entire course of the trial. For postnatal weights from birth until cessation of the experiment (day 550), there was an age effect $(P<0.01$, data not shown), but no nutritional group effect on weight, and no group $\times$ age interaction. The number of lambs born to each maintenance ewe was 1.9 with an average weight of $5.6 \mathrm{~kg} \pm 0.2$, while for restricted dams the number of lambs born per ewe was also 1.9 with an average weight of $5.4 \pm 0.3 \mathrm{~kg}$ (Table 1 ).
At the completion of the trial, ewes from maintenance dams weighed $68.9 \pm 1.6 \mathrm{~kg}$ while ewes from restricted dams weighed $70.1 \pm 2.5 \mathrm{~kg}$.

\section{Attainment of puberty}

Restricted nutrition did not affect the timing of puberty onset. All ewes displayed estrous on at least one occasion between 6 and 9 months of age. For ewes from maintenance dams $(n=17)$, the first recorded mating mark was $218 \pm 5$ days after birth (range 185-241), while for the ewes from restricted dams $(n=13)$, this was an average of $225 \pm 3$ days (range 211-240).

During the female offspring's second breeding season, the gestational nutritional status of the ewes dam did not affect either the timing of the onset of estrous behavior or the length of the estrous cycles $(16.4 \pm 0.8$ days for maintenance animals and $16.4 \pm 0.7$ days for restricted animals). 


\section{Indicators of fertility}

There was no effect of technique (laparoscopy vs ultrasound scanning) on OR. At 8 months of age, OR was $1.5 \pm 0.1$ by laparoscopy, whereas by ultrasound scanning OR was $1.3 \pm 0.1$. At 19 months of age, OR was 1.8 by both laparoscopy and ultrasound scanning. Overall, for $O R$ there were effects of age $(P<0.01)$ and nutritional group $(P<0.01)$. The group $\times$ age interaction indicated a trend $(P=0.1)$. For AFC counts there were effects of age $(P<0.01)$ and nutritional group $(P<0.01)$. A group $\times$ age interaction $(P<0.05)$ was present. On this basis, data for each age are presented and analyzed separately using ANOVA (Table 5) to determine group differences at each age. At 8 months of age, the nutritional status of the dam did not affect either OR or AFC. At 19 months of age, ewes from dams exposed to restricted gestational nutrition had higher OR $(26 \%$ increase) and the ovaries contained more antral follicles $>2 \mathrm{~mm}$ (44\% increase).

\section{Progesterone in female offspring}

Progesterone concentrations on each day throughout a complete estrous cycle of all 19-month-old female offspring ( $n=13$ from 12 restricted dams and 17 from 14 maintenance dams) are presented in Fig. 4. A nutritional group effect was noted $(P=0.04)$, and this group effect was independent of OR which had no effect on progesterone concentrations $(P=0.29)$. There was no group $x$ day of the cycle interaction. Multiple range tests (Bonferroni) indicate that these group differences are apparent during the early stages of the estrous cycle where progesterone concentrations are rising, with ewes from restricted dams having higher progesterone concentrations than those ewes from maintenance dams.

Table 5 Indicators of fertility in female offspring at 8 and 19 months of age.

\begin{tabular}{lccc}
\hline & Maintenance & Restricted & $P$ value \\
\hline Animals, $n$ & 17 & 13 & \\
Dams, $n$ & 13 & 12 & \\
Age/fertility indicator & & & \\
$\quad 8$ months & & & \\
$\quad$ OR & $1.4 \pm 0.1$ & $1.5 \pm 0.1$ & 0.4 \\
$\quad$ AFC* & $17.3 \pm 1.3$ & $19.6 \pm 2.6$ & 0.8 \\
19 months & & & \\
$\quad$ OR & $1.6 \pm 0.1$ & $2.1 \pm 0.1$ & $<0.01$ \\
$\quad$ AFC* & $6.8 \pm 0.5$ & $9.8 \pm 0.6$ & $<0.01$ \\
\hline
\end{tabular}

Ovulation rate (OR) data is the mean and standard error of two laparoscopic and two ultrasound measurements over four successive cycles. Antral follicle count (AFC) is the mean and standard error of two ultrasound observations. Effective $n$ value $=$ number of dams $(13$ and 12), data from animals from the same dam were averaged prior to analysis.

*The presence of a significant age $\times$ nutritional group interaction $(P<0.05)$.

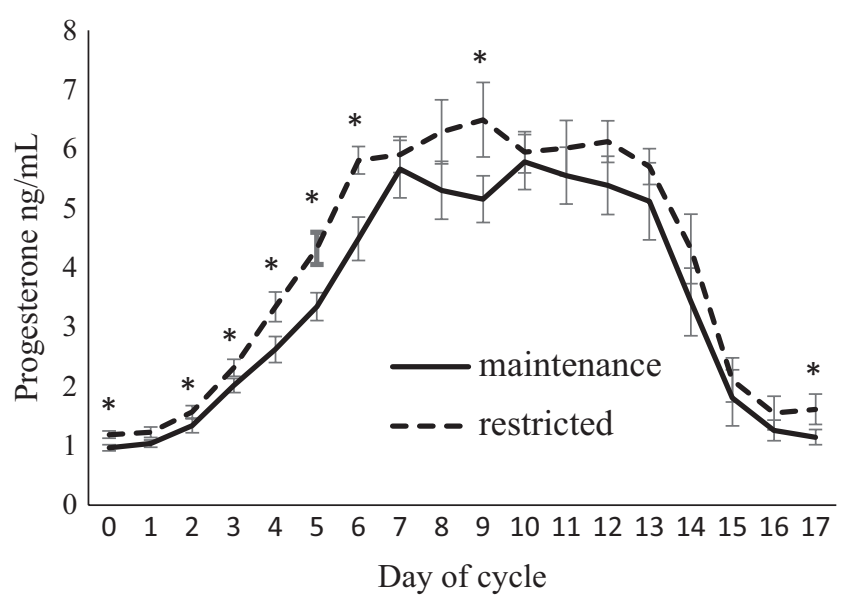

Figure 4 Daily progesterone concentrations in female offspring throughout the estrous cycle. Data are presented as means and SE for 17 animals from 13 maintenance dams (solid line) and 13 animals from 12 restricted dams (dashed line). *Indicates significant group difference $P>0.05$, Bonferrroni multiple ranges tests.

\section{FSH in female offspring}

A randomly chosen subset of 12 ewes from 12 maintenance dams and 12 ewes from 12 restricted dams were used to determine daily FSH concentrations throughout a complete estrous cycle (Fig. 5). There was no overall effect of nutritional group $(P=0.2)$. However, there was an effect of day of the cycle $(P<0.01)$, and a day of the cycle $\times$ group interaction $(P<0.01)$. As assessed by multiple range tests (Bonferroni), ewes from dams exposed to restricted nutrition (0.6 maintenance from day 0 to day 55 of gestation) had lower FSH concentrations on days 3,4 and 5 of the estrous cycle when compared with ewes from dams on maintenance nutrition (Fig. 5).

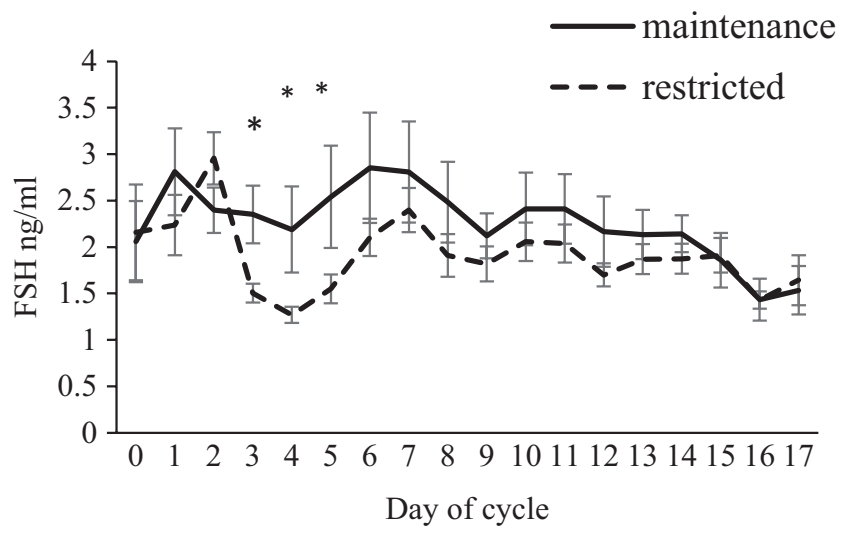

Figure 5 Daily FSH concentration in female offspring throughout the estrous cycle. Data are presented as means and S.E. for 12 animals from maintenance dams (solid line) and 12 animals from restricted dams (dashed line). GLM indicated no overall nutritional group effect but, a day of the cycle effect $(P<0.01)$ and a day of the cycle $\times$ nutritional group interaction $(P<0.01)$. *Indicates significant group difference $P>0.05$, Bonferrroni multiple ranges tests. 
Table 6 Pattern of LH secretion in female offspring.

\begin{tabular}{lccc}
\hline Variable & Maintenance & Restricted & P value \\
\hline Sum of all values $(\mathrm{ng} / \mathrm{mL})$ & $31.2 \pm 5.0$ & $28.6 \pm 2.3$ & 0.636 \\
Basal level $(\mathrm{ng} / \mathrm{mL})$ & $0.54 \pm 0.1$ & $0.58 \pm 0.1$ & 0.728 \\
Number of major peaks & $1.3 \pm 0.5$ & $1.9 \pm 0.3$ & 0.103 \\
Average major peak amplitude $(\mathrm{ng} / \mathrm{mL})$ & $3.2 \pm 0.5$ & $2.4 \pm 0.3$ & 0.117 \\
Number of minor peaks & $0.9 \pm 0.4$ & $1.1 \pm 0.2$ & 0.616 \\
Average minor peak amplitude $(\mathrm{ng} / \mathrm{mL})$ & $0.4 \pm 0.2$ & $0.4 \pm 0.1$ & 0.886 \\
\hline
\end{tabular}

Results are expressed as means and standard errors for ten female offspring from maintenance dams and ten from restricted dams. No significant group differences were identified.

\section{$L H$ in female offspring}

A subset of ten ewes from maintenance dams and ten ewes from restricted dams were used to analyze the pattern of LH secretion on day 5-6 of the 2 nd cycle following synchronization. Analysis of the pulsatile pattern of LH secretion using samples collected every 15 min over an 8-h period did not identify any effects on any of the variables analyzed attributable to the gestational nutrition regime of the ewes' dam (Table 6). This includes pulse frequency, pulse amplitude, basal secretion concentration and total $\mathrm{LH}$ secreted over the 8-h period.

\section{Discussion}

In this study, a restricted plane of gestational nutrition (0.6 of maintenance for the first 55 days) followed by ad libitum feeding altered the pattern of fetal germ cell development (increased germ cell numbers at day 75) and, unexpectedly, resulted in higher indicators of fertility (OR, AFC and progesterone) in female offspring when compared with offspring from control dams. While these are good indicators of fertility, it is yet to be established whether the observed differences in OR, $\mathrm{AFC}$ and progesterone translate into differences in the number of lambs born (NLB). While the increase in indicators of fertility is a novel finding, previous studies have also reported differences in germ cell development similar to those reported in the current study. However, the time points used in the current study (in relation to dietary changes) have been able to highlight the potential importance of changes in diet rather than continual exposure to a restricted diet.

To our knowledge, only one other study has suggested increased fertility in offspring resulting from differences in gestational nutrition. Asmad et al. reported a modest increase in NLB to adult sheep from dams exposed to ad libitum gestational nutrition between days 21 and 140 of gestation, compared with maintenance nutrition (Asmad et al. 2014). However, the nutritional regime employed differed compared with the current study, and Asmad reported no differences in AFC or OR, consistent with a mechanism targeting embryo/fetal survival, perhaps similar to the increased progesterone concentrations observed in the current study. With respect to the lack of group differences in OR and AFC at 8 months of age observed in the current study, previous work has shown that New Zealand sheep at this age have lower fertility, including a lower OR, than their adult counterparts (Edwards et al. 2016). Thus, there are other mechanisms affecting fertility in sheep at this age in addition to any potential mechanisms introduced through alterations to gestational nutrition.

Arguably, the observed increases in AFC and OR in this study are supported by the lower concentrations of FSH observed in ewes from restricted dams (Robertson et al. 2016). The differences in FSH concentrations are evident around the time of emergence of the first follicle wave, days 3-5 of the estrous cycle (Baby \& Bartlewski 2011), with this follicle wave known to be particularly active in the production of inhibin (Souza et al. 1998). The lower concentrations of $\mathrm{FSH}$ observed in ewes from restricted dams at this time is consistent with increased negative feedback from inhibin produced by the increased numbers of follicles in these animals.

A number of studies show a link between high progesterone concentrations and increased embryo survival, with this link particularly evident early in gestation (Diskin \& Niswender 1989, O'Connell et al. 2013). The early rise in progesterone concentrations, evident in female offspring from restricted dams, suggests that the increased OR and AFC observed in these animals has the potential to be accompanied by increased embryo survival. Thus, while this study does not examine NLB, the results provide strong evidence supporting the concept that fertility in the offspring from restricted dams is likely to be higher than those animals from maintenance dams.

The question immediately posed by these novel results is, why are increased indicators of fertility apparent in adult ewes from restricted dams where most previous studies report decreased fertility? (Rae et al. 2002, Long et al. 2010). Arguably, the three variables likely to account for the novel results in this study are (a) the degree of nutrition restriction, (b) the timing of nutrition restriction and (c) the postrestriction diet.

Most published studies in sheep use a restriction equivalent to $50 \%$ of maintenance (Rae et al. 2001, Murdoch et al. 2003, Kotsampasi et al. 2009) whereas, 
in the current study, dietary restriction was calculated at $60 \%$ of maintenance. While the difference between 60 and $50 \%$ of maintenance may appear small, effects on the animal can be profound. In this study, pregnant ewes exposed to restricted nutrition lost $7 \%$ of their body weight over the 55-day period. Studies using 50\% of maintenance over a similar time period resulted in a loss of $16 \%$ of body weight (Rae et al. 2001). Potentially, the less severe restriction used in this study may not have been sufficient to induce changes that result in negative effects on postnatal fertility.

The timing of nutrition restriction also varies considerably between studies, encompassing intervals from the preconception period through until term. In this study, nutrition restriction ended at day 55 of gestation, just as key germ cell processes such as meiosis and apoptosis are becoming prevalent (Smith et al. 1993). The selection of this time period (day 0 to day 55) may therefore have avoided any negative impacts of restricted nutrition on these key processes. In general, studies using a restricted plane of nutrition during the first trimester while altering aspects of fetal ovarian development (Borwick et al. 1997, Rae et al. 2001) and on occasions altering aspects of adult physiology (Rae et al. 2002, Kotsampasi et al. 2009) have not been reported as negatively affecting the fertility of the female offspring.

Following the restricted nutrition period, animals in this study were fed ad libitum, resulting in those animals exposed to restricted nutrition showing a greater growth rate than control animals following the change of diet. The potential importance of the change of diet is reinforced by the fetal germ cell data. At day 55 of gestation, no differences were evident in fetal germ cell numbers. However, 20 days after the change to ad libitum feeding, ovaries from fetuses whose dams were exposed to restricted nutrition contained more germ cells than those from maintenance fetuses. The lack of differences in key germ cell processes (autophagy and apoptosis) at both day 55 and day 75 suggests the mechanism which underlies the increased germ cell number may be active for only a brief window following the change of diet. This concept is supported by the observation of lower germ cell proliferation in restricted fetal ovaries at day 75 , when numbers are higher than those in maintenance fetal ovaries, again suggesting the mechanism by which increased germ cell numbers are established has already run its course. Thus, while the timing and degree of the nutrition restriction used in this study are likely to have contributed to the novel results, the data suggest that the change in diet from restricted to ad libitum is critical. The importance of changes in the maternal environment and the effects of such changes on fetal ovarian development has been proposed previously. With respect to exposure to endocrinedisrupting chemicals (EDCs) and the negative impacts of these compounds on ovarian development, Lea et al. conclude that changes in exposure are more detrimental to ovarian development than a continual exposure to EDCs (Lea et al. 2016).

In the current study, stereological techniques were used to quantify germ cells. These techniques not only estimate the numbers of germ cells within the organ (rather than cell density), but also take into account ovarian or cortical volumes, as well as potential differences in germ cell size. At day 75, in fetal ovaries from restricted dams, the stereology data report increased germ cell numbers (1.5-fold), ovarian volumes (1.2-fold) and ovarian cortex volumes (1.3-fold). Calculating and analyzing germ cell densities from the current data (germ cell number/either ovarian or cortical volume) showed that while at day 75 germ cell numbers were greater in restricted ovaries, germ cell densities between the two groups at day 75 were not different, a result in line with previous studies (Rae et al. 2001, Murdoch et al. 2003). Thus, in addition to the differences in timing of nutrition and ages studied, differences in techniques used to quantify germ cells may have contributed to differences in results between the current study and previous studies.

At a simplistic level, increased numbers of germ cells observed at day 75 can only arise through increased proliferation or decreased cell death. Perhaps counterintuitively the germ cell proliferation rate as assessed by $\mathrm{Ki}-67$ staining is less in restricted ovaries at day 75. Lea et al. (2006) reported decreased Ki-67 staining at day 67 following restricted nutrition from mating until day 30 , a delayed response similar to that observed in the current study. This implies a shift in the timing of germ cell development by a mechanism which functions during the day 55-75 window.

Similarly, the lack of group differences in TUNEL staining suggest that apoptosis has not been affected by the restricted nutrition, at least at the ages examined. While apoptosis is considered the primary mechanism by which fetal germ cells are lost (Tingen et al. 2009), there is the likelihood of alternative mechanisms of germ cell loss not examined in the current study. The range of morphologies shown in Fig. 2, along with lack of staining for TUNEL and MAPLC3 for some germ cells showing morphological evidence of cell death, would seem to support this concept. Both Wartenberg et al. (2001) and McClellan et al. (2003) report a novel nonapoptotic cell death pathway which may be responsible for a considerable amount of germ cell loss. Given this, while the density of apoptotic germ cells, and the area staining positive for autophagy is similar between the nutritional groups at both ages, differences in germ cell loss between groups cannot yet be discounted as a mechanism underlying the observed difference in germ cell numbers.

The staining pattern observed, for MAPLC3B (staining less widespread at day 75 when apoptosis of germ cells is increasing markedly) appears consistent with the findings of Gawriluk et al. (2011). In the mouse, 
Gawriluk concluded that autophagy may be an important regulator of germ cell survival prior to the formation of the primordial follicle pool. As with TUNEL staining, no group differences were apparent in the percentage of cortical area staining positive for MAPLC3B. However, it was noted that, regardless of nutritional group, the more developmentally advanced the germ cell then the less MAPLC3B staining. Further, germ cells in restricted fetal ovaries at day 75 showed slightly less dense staining compared with germ cells from maintenance ovaries. These two observations are consistent with a shift in the timing of germ cell development with those germ cells in restricted fetal ovaries being potentially more developmentally advanced when compared with germ cells from maintenance ovaries. Thus, the three key determinants of germ cell number (proliferation, apoptosis and germ cell survival) largely fail to support the difference in germ cell number evident at day 75 . Collectively, these results are consistent with the concept that the mechanism by which increased germ cell numbers are established in fetal ovaries at day 75 may be functional for a brief window following the change from restricted to ad libitum nutrition. While the fetal ovarian data presented here does not identify the nature of such a mechanism, the companion paper (Smith et al. 2019) examining gene expression in the fetal ovaries raises the potential importance of nitric oxide pathways and also protease inhibitors.

This study did not examine gestational ages late enough to establish effects on the ovarian reserve, it therefore remains to be determined whether the differences in germ cells translate to differences in the ovarian reserve or, reflect a shift in the timing of development, and that given time, germ cell numbers in maintenance animals reach parity with restricted animals. Rae reported delayed effects of undernutrition (undernutrition from day $0-30$ or 31-50) on the patterns of follicle development at day 110 of gestation, where periods of undernutrition increased the density of primordial follicles but decreased the density of growing follicles (Rae et al. 2001). Such delayed effects confound interpretation of any potential relationship between germ cell numbers at day 55 or 75 of gestation and ovarian reserve (follicle numbers in late gestation).

The changes in the albumin and creatinine concentrations are in line with previous studies (Keenan \& Allardyce 1986, Caldeira et al. 2007). The group differences reported in maternal $\mathrm{Ca}^{2+}$ concentrations however is a new finding. Of the factors in the metabolic panel, $\mathrm{Ca}^{2+}$ appears most likely to potentially contribute to the differences observed in ovarian development. The similarities in maternal and fetal electrolyte concentrations at day 75 would suggest that the group differences in maternal $\mathrm{Ca}^{2+}$ concentrations at day 55 may also be present in fetal plasma at day 55 . While this potential difference remains to be established, it may have important ramifications given the importance of $\mathrm{Ca}^{2+}$ to numerous cell processes (Carroll et al. 1996, Verkhratsky 2007, Capiod 2011).

Increased maternal progesterone concentrations observed in this study are unlikely to have direct effects on fetal gonadal development. While a close association exists between progesterone metabolites in fetal and maternal circulations, there is no such correlation in progesterone concentrations (Hill et al. 2009). Rasby reported elevated maternal estradiol concentrations late in gestation following early gestational nutritional restriction in cattle (Rasby et al. 1990). Using LC-MS analysis, estradiol was detectable in maternal plasma at days 55 (12 of 22 samples) and 75 (14 of 15 samples) of pregnancy, with no group effects evident. Results from the current study do not support a role of steroids in establishing the differences observed in fetal ovarian development and adult female offspring, a conclusion supported by the lack of differential expression of steroidogenic genes in the fetal ovary reported in the companion paper (Smith et al. 2019.

In conclusion, this study, while not examining definitive fertility (NLB), has demonstrated increased indicators of fertility (AFC, OR and progesterone concentrations) in female offspring from dams exposed to restricted gestational nutrition. Further, in the same cohort of animals, changes in fetal ovarian germ cell development following the change from restricted to ad libitum feeding were observed. While the mechanisms underlying the establishment of this phenotype in female offspring are still to be fully established, both germ cell development and the timing of the dietary changes appear important.

\section{Supplementary data}

This is linked to the online version of the paper at https://doi.org/10.1530/REP-18-0357.

\section{Declaration of interest}

The authors declare that there is no conflict of interest that could be perceived as prejudicing the impartiality of the research reported.

\section{Funding}

This work was supported by AgResearch through the New Zealand Governments Strategic Science Investment Fund, and the Department of Anatomy, University of Otago.

\section{References}

Asmad K, Kenyon PR, Pain SJ, Parkinson TJ, Peterson SW, Lopez-Villalobos N \& Blair HT 2014 Effects of dam size and nutrition during pregnancy on lifetime performance of female offspring. Small Ruminant Research 121 325-335. (https://doi.org/10.1016/j.smallrumres.2014.07.024) 
Baby TE \& Bartlewski PM 2011 Circulating concentrations of ovarian steroids and follicle-stimulating hormone (FSH) in ewes with 3 or 4 waves of antral follicle emergence per estrous cycle. Reproductive Biology 11 19-36. (https://doi.org/10.1016/S1642-431X(12)60061-8)

Berlinguer F, Gonzalez-Bulnes A, Spezzigu A, Contreras-Solis I, Succu S, McNeilly AS, Naitana S \& Leoni GG 2012 Effect of aging on follicular function may be relieved by exogenous gonadotropin treatment in a sheep model. Reproduction 144 245-255. (https://doi.org/10.1530/REP12-0030)

Borwick SC, Rhind SM, McMillen SR \& Racey PA 1997 Effect of undernutrition of ewes from the time of mating on fetal ovarian development in mid gestation. Reproduction, Fertility and Development 9 711-716. (https://doi.org/10.1071/R97011)

Caldeira RM, Belo AT, Santos CC, Vazques MI \& Portugal AV 2007 The effect of body condition score on blood metabolites and hormonal profiles in ewes. Small Ruminant Research 68 233-241. (https://doi. org/10.1016/j.smallrumres.2005.08.027)

Capiod T 2011 Cell proliferation, calcium influx and calcium channels. Biochimie 93 2075-2079. (https://doi.org/10.1016/j.biochi.2011.07.015)

Carroll J, Jones K \& Whittingham D 1996 Ca2+ release and the development of $\mathrm{Ca} 2+$ release mechanisms during oocyte maturation: a prelude to fertilization. Reviews of Reproduction 1 137-143. (https://doi. org/10.1530/ror.0.0010137)

Clarke IJ \& Cummins JT 1987 The significance of small pulses of gonadotrophin-releasing hormone. 113413.

Diskin MG \& Niswender GD 1989 Effect of progesterone supplementation on pregnancy and embryo survival in ewes. Journal of Animal Science 67 1559-1563. (https://doi.org/10.2527/jas1989.6761559x)

Edwards SJ, Juengel JL, O'Connell AR, Johnstone PD, Farquhar PA \& Davis GH 2015 Attainment of puberty by ewes in the first year of life is associated with improved reproductive performance at 2 years of age. Small Ruminant Research 123 118-123. (https://doi.org/10.1016/j. smallrumres.2014.11.006)

Edwards SJ, Smaill B, O'Connell AR, Johnstone PD, Stevens DR, Quirke LD, Farquhar PA \& Juengel JL 2016 Reduced ovulation rate, failure to be mated and fertilization failure/embryo loss are the underlying causes of poor reproductive performance in juvenile ewes. Animal Reproduction Science 167 125-132. (https://doi.org/10.1016/j. anireprosci.2016.02.017)

Evans ACO, Mossa F, Walsh SW, Scheetz D, Jimenez-Krassel F, Ireland JLH, Smith GW \& Ireland J 2012 Effects of maternal environment during gestation on ovarian folliculogenesis and consequences for fertility in bovine offspring. Reproduction in Domestic Animals 47 31-37. (https:// doi.org/10.1111/j.1439-0531.2012.02052.x)

Gawriluk TR, Hale AN, Flaws JA, Dillon CP, Green DR \& Rucker EB 2011 Autophagy is a cell survival program for female germ cells in the murine ovary. Reproduction 141 759-765. (https://doi.org/10.1530/REP-100489)

Gleit A 1985 Estimation for small normal data sets with detection limits. Environmental Science and Technology 19 1201-1206. (https://doi. org/10.1021/es00142a011)

Goodman RL \& Karsch FJ 1980 Pulsatile secretion of luteinizing hormone: differential suppression by ovarian steroids. Endocrinology $\mathbf{1 0 7}$ 1286-1290. (https://doi.org/10.1210/endo-107-5-1286)

Gundersen HJ \& Jensen EB 1987 The efficiency of systematic sampling in stereology and its prediction. Journal of Microscopy 147 229-263. (https://doi.org/10.1111/j.1365-2818.1987.tb02837.x)

Harwood DT \& Handelsman DJ 2009 Development and validation of a sensitive liquid chromatography-tandem mass spectrometry assay to simultaneously measure androgens and estrogens in serum without derivatization. Clinica Chimica Acta 409 78-84. (https://doi. org/10.1016/j.cca.2009.09.003)

Hill M, Pariezek A, Jirasek J \& Starka L 2009 Is maternal progesterone actually independent of the fetal steroids? Physiological Research/ Academia Scientiarum Bohemoslovaca 59 211-224.

Keenan DM \& Allardyce CJ 1986 Changes in plasma creatinine levels of sheep during submaintenance feeding. Australian Veterinary Journal 63 29-30. (https://doi.org/10.1111/j.1751-0813.1986.tb02871.x)

Kelly RW \&Allison AJ 1976 Measurement of ovulation rates by laparoscopy and effects on reproductive performance. Proceedings of NZ Society for Animal Production 36 240-246.
Kenyon PR, Maloney SK \& Blache D 2014 Review of sheep body condition score in relation to production characteristics. New Zealand Journal of Agricultural Research 57 38-64. (https://doi.org/10.1080/00288233.20 13.857698)

Kotsampasi B, Chadio S, Papadomichelakis G, Deligeorgis S, Kalogiannis D, Menegatos I \& Zervas G 2009 Effects of maternal undernutrition on the hypothalamic-pituitary-gonadal axis function in female sheep offspring. Reproduction in Domestic Animals 44 677-684. (https://doi. org/10.1111/j.1439-0531.2007.01046.x)

Lea RG, Andrade LP, Rae MT, Hannah LT, Kyle CE, Murray JF, Rhind SM \& Miller DW 2006 Effects of maternal undernutrition during early pregnancy on apoptosis regulators in the ovine fetal ovary. Reproduction 131 113-124. (https://doi.org/10.1530/rep.1.00844)

Lea RG, Amezaga MR, Loup B, Mandon-Pépin B, Stefansdottir A, Filis P, Kyle C, Zhang Z, Allen C, Purdie L et al. 2016 The fetal ovary exhibits temporal sensitivity to a 'real-life' mixture of environmental chemicals. Scientific Reports 6 22279. (https://doi.org/10.1038/srep22279)

Long NM, Nijland MJ, Nathanielsz PW \& Ford SP 2010 The effect of early to mid-gestational nutrient restriction on female offspring fertility and hypothalamic-pituitary-adrenal axis response to stress. Journal of Animal Science 88 2029-2037. (https://doi.org/10.2527/jas.2009-2568)

Lumey LH \& Stein AD 1997 In utero exposure to famine and subsequent fertility: the Dutch Famine Birth Cohort Study. American Journal of Public Health 87 1962-1966. (https://doi.org/10.2105/AJPH.87.12.1962)

McClellan KA, Gosden R \& Taketo T 2003 Continuous loss of oocytes throughout meiotic prophase in the normal mouse ovary. Developmental Biology 258 334-348. (https://doi.org/10.1016/S00121606(03)00132-5)

McNatty K, Gibb M, Dobson C, Thurley D \& Findlay J 1981 Changes in the concentration of gonadotrophic and steroidal hormones in the antral fluid of ovarian follicles throughout the oestrous cycle of the sheep. Australian Journal of Biological Sciences 34 67-80. (https://doi. org/10.1071/BI9810067)

Meikle D \& Westberg M 2001 Maternal nutrition and reproduction of daughters in wild house mice (Mus musculus). Reproduction 122 437-442. (https://doi.org/10.1530/rep.0.1220437)

Murdoch W, Van Kirk E, Vonnahme K \& Ford S 2003 Ovarian responses to undernutrition in pregnant ewes, USA. Reproductive Biology and Endocrinology 1 1-8. (https://doi.org/10.1186/1477-7827-1-1)

O'Connell AR, Hurst PR, Davis GH, McNatty KP, Taylor SL \& Juengel JL 2013 An earlier rise in systemic progesterone and increased progesterone in the uterine vein during early pregnancy are associated with enhanced embryonic survival in the ewe. Theriogenology 80 269-274. (https://doi. org/10.1016/j.theriogenology.2013.04.006)

Rae M, Palassio S, Kyle C, Brooks A, Lea R, Miller D \& Rhind S 2001 Effect of maternal undernutrition during pregnancy on early ovarian development and subsequent follicular development in sheep fetuses. Reproduction 122 915-922. (https://doi.org/10.1530/rep.0.1220915)

Rae MT, Kyle CE, Miller DW, Hammond AJ, Brooks AN \& Rhind SM 2002 The effects of undernutrition, in utero, on reproductive function in adult male and female sheep. Animal Reproduction Science 72 63-71. (https://doi.org/10.1016/S0378-4320(02)00068-4)

Rasby RJ, Wettemann RP, Geisert RD, Rice LE \& Wallace CR 1990 Nutrition, body condition and reproduction in beef cows: fetal and placental development, and estrogens and progesterone in plasma. Journal of Animal Science 68 4267-4276. (https://doi. org/10.2527/1990.68124267x)

Robertson DM, Lee CH \& Baerwald A 2016 Interrelationships among reproductive hormones and antral follicle count in human menstrual cycles. Endocrine Connections 5 98-107. (https://doi.org/10.1530/EC-16-0077)

Smith P, O WS, Hudson NL, Shaw L, Heath DA, Condell L, Phillips DJ \& McNatty KP 1993 Effects of the Booroola gene (FecB) on body weight, ovarian development and hormone concentrations during fetal life. Journal of Reproduction and Fertility 98 41-54. (https://doi.org/10.1530/ jrf.0.0980041)

Smith P, Juengel J, Maclean P, Rand C \& Stanton J-A L 2019 Gestational nutrition 2: gene expression in sheep fetal ovaries exposed to gestational under nutrition. Reproduction 157 13-25. (https://doi.org/10.1530/REP18-0358)

Souza C, Campbell B \& Baird D 1998 Follicular waves and concentrations of steroids and inhibin $\mathrm{A}$ in ovarian venous blood during the luteal phase 
of the oestrous cycle in ewes with an ovarian autotransplant. Journal of Endocrinology 156 563-572. (https://doi.org/10.1677/joe.0.1560563)

Sterio DC 1984 The unbiased estimation of number and sizes of arbitrary particles using the disector. Journal of Microscopy 134 127-136. (https:// doi.org/10.1111/j.1365-2818.1984.tb02501.x)

Tingen CM, Bristol-Gould SK, Kiesewetter SE, Wellington JT, Shea L \& Woodruff TK 2009 Prepubertal primordial follicle loss in mice is not due to classical apoptotic pathways. Biology of Reproduction 81 16-25. (https://doi.org/10.1095/biolreprod.108.074898)

Verkhratsky A 2007. Calcium and cell death. In Calcium Signalling and Disease: Molecular Pathology of Calcium, Eds E Carafoli and M Brini, pp. 465-480, Switzerland: Springer Nature.
Wartenberg H, Ihmer A, Schwarz S, Miething A \& Viebahn C 2001 Mitotic arrest of female germ cells during prenatal oogenesis. A colcemid-like, non-apoptotic cell death. Anatomy and Embryology 204 421-435. (https://doi.org/10.1007/s00429-001-0216-7)

Received 11 July 2018

First decision 13 August 2018

Revised manuscript received 5 November 2018

Accepted 10 December 2018 